\title{
Composition and vertical distribution of metazoan meiofauna assemblages on the continental shelf off central Chile
}

\author{
Eulogio Soto ${ }^{1}$, Williams Caballero ${ }^{1}$ \& Eduardo Quiroga ${ }^{2}$ \\ ${ }^{1}$ Facultad de Ciencias del Mar y de Recursos Naturales, Universidad de Valparaíso \\ P.O. Box 5080, Reñaca, Viña del Mar, Chile \\ Escuela de Ciencias del Mar, Pontificia Universidad Católica de Valparaíso \\ P.O. Box 1020, Valparaíso, Chile \\ Corresponding author: Eulogio Soto (eulogio.soto@uv.cl)
}

\begin{abstract}
A quantitative study of metazoan meiofauna was carried out in Valparaiso Bay $\left(33^{\circ} \mathrm{S} 71^{\circ} \mathrm{W}\right)$ which is affected by seasonal hypoxia in central Chile. The contents of bottom water, dissolved oxygen (BWDO), organic carbon, chloroplast pigments and composition of stable carbon isotope $\left(\delta^{13} \mathrm{C}\right)$ in the sediment were used as a measure of the contribution of primary production in the water column, which accumulates in the sediment. Meiofauna abundances in the three sampling stations (80-140 m depth) ranged from $2.218 \pm 643$ to $1.592 \pm 148$ ind $10 \mathrm{~cm}^{-2}$. Nine upper metazoan meiofauna groups were recorded, with nematodes as the dominant group, contributing with more than $95 \%$ of total abundances. The abundance vertical distribution was concentrated in the first layers of sediment in most groups except Acari and nauplii larvae. Canonical correspondence analysis revealed significant correlations $(P<0.05)$ between the meiofauna abundance and organic content, depth and redox potential from sediments. These results represent a first approach to understanding the ecology of meiofaunal assemblages in the Valparaiso Bay and may be useful as a baseline for future comparisons and descriptions of the ENSO (El Niño Southern Oscillation) and seasonal variations of these unknown benthic communities.
\end{abstract}

Keywords: meiofauna, nematodes, abundance, sediment, Valparaiso Bay, southeastern Pacific.

\section{Composición y distribución vertical de los ensambles de meiofauna metazoaria en la plataforma continental frente a Chile central}

\begin{abstract}
RESUMEN. Se realizó un estudio cuantitativo de la meiofauna metazoaria en la Bahía de Valparaíso $\left(33^{\circ} \mathrm{S}\right.$, $71^{\circ} \mathrm{W}$ ), afectada por hipoxia estacional en Chile central. Los contenidos de oxígeno disuelto en el agua de fondo, carbono orgánico, pigmentos cloroplásticos y composición de isotopos estables de carbono en el sedimento $\left(\delta^{13} \mathrm{C}\right)$ se usaron como una medida del aporte de producción primaria en la columna de agua, que se acumula en el sedimento. La abundancia de la meiofauna en las tres estaciones de muestreo (80-140 m de profundidad) varió de $2.218 \pm 643$ a $1.592 \pm 148$ ind $10 \mathrm{~cm}^{-2}$. Se registraron nueve grupos superiores de la meiofauna metazoaria, siendo los nemátodos el grupo dominante, contribuyendo con más de $95 \%$ de la abundancia total. La distribución vertical de la abundancia se concentró en las primeras capas del sedimento en la mayoría de los grupos a excepción de Acari y larvas nauplii. El análisis de correspondencia canónico reveló correlaciones significativas $(P<0,05)$ entre la abundancia de la meiofauna y el contenido orgánico, profundidad y potencial redox de los sedimentos. Estos resultados representan una primera aproximación al conocimiento de la ecología de ensambles de meiofauna de fondos blandos en la Bahía de Valparaíso y pueden ser útiles como línea de base para futuras comparaciones y descripciones de las condiciones ENSO (El Niño Oscilación del Sur) y las variaciones estacionales de estas desconocidas comunidades bentónicas.
\end{abstract}

Palabras clave: meiofauna, nematodos, abundancia, sedimentos, Bahía de Valparaíso, Pacífico suroriental.

\section{INTRODUCTION}

The seafloor benthic assemblages inhabiting the continental shelf off north and central Chile are influen- ced by several oceanographic features such as oxygen minimum zones (OMZs) (Gallardo et al., 2004; Sellanes et al., 2007, 2010; Fuenzalida et al., 2009, Ulloa \& Pantoja, 2009), coastal upwelling (Fossing et

Corresponding editor: Claudia Bremec 
al., 1995; Gutiérrez et al., 2006) and the ENSO events (Arntz et al., 1991; Neira et al., 2001a, 2001b; Sellanes et al., 2007; Moreno et al., 2008). In this region, a large fraction of the organic matter derived from primary production is accumulated on the sediment, which is characterized by having high remineralization rates (Gutiérrez et al., 2000). These factors may change the biochemical properties of the sediments (Cowie, 2005; Neira et al., 2013) and bottom water column with observable effects on the composition, abundance, diversity and distribution of benthic fauna as has been observed in another regions (Levin, 2003; Gooday et al., 2009, 2010).

The meiofauna represents the most abundant metazoan group in the marine benthic system, distributed from the intertidal to abyssal depths, and with productivity rates similar to or higher than those of macrofauna (Gerlach, 1971; Giere, 2009). The meiofauna enhance organic matter biomineralization enhancing the recycling of nutrients and organic carbon making them available for assimilation into new biomass (e.g., Gerlach, 1971; Fenchel, 1978; Giere, 2009; Neira, et al., 2013). In addition, these communities are also food supply for a large number of larger organisms and show sensitivity to anthropogenic impacts, serving as environmental indicators (Boyd et al., 2000). Meiobenthic studies from Chilean waters have been carried out from intertidal (Asencio et al., 1995; Rodríguez et al., 2001; Lee \& Riveros, 2012; Valderrama-Aravena et al., 2014), continental shelf (Neira et al., 2001a, 2001b; Sellanes et al., 2003; Sellanes \& Neira, 2006; Veit- Köhler et al., 2009; Neira et al., 2013) and hadal trenches environments (Danovaro et al., 2002; Gambi et al., 2003). There are also studies on the use of these organisms as anthropogenic bioindicators (Lee et al., 2006; Lee \& Correa, 2007) and their relationships with abiotic parameters from sediments in fjords ecosystems (Chen et al., 1999; George \& Schminke, 1999; Stead et al., 2011).

Investigations made on the continental shelf have been mostly developed off Concepción, south central Chile ( $\left.36^{\circ} 40^{\prime} \mathrm{S}\right)$. They have focused on describing the composition, structure and function of meiofaunal assemblages in response to ENSO and OMZs conditions as well as their function in the energetic flux of benthic systems (Sellanes et al., 2003; Sellanes \& Neira, 2006; Neira et al., 2013). In Valparaíso Bay $\left(33^{\circ} \mathrm{S}\right)$, there are limited studies on continental shelf mega- and macrobenthic communities (Andrade, 1986, 1987) and virtually there are no studies about the meiobenthos. Therefore, the current research is the first to investigate the composition and community structure of soft bottom meiofauna assemblages in Valparaíso
Bay. The aims were a) to describe the taxonomic composition, density and vertical distribution of the metazoan meiofauna, and b) to characterize environmental factors influencing the meiofauna distribution.

\section{MATERIALS AND METHODS}

\section{Study area}

Valparaíso Bay $\left(32^{\circ} 9^{\prime} \mathrm{S}, 71^{\circ} 6 \mathrm{~W}\right)$ is located on the continental shelf off central Chile. In this area, oceanographic process such as upwelling, OMZs, ENSO and local organic enrichment associated with sewage outfalls influence sediment conditions and benthic communities (Brandhorst, 1971; Andrade et al., 1986; Sievers \& Vega, 2000; Silva \& Valdenegro, 2003; Rutllant et al., 2004; Bello \& Maturana, 2004). In addition, terrestrial inputs from Aconcagua River contribute to organic enrichment and habitat heterogeneity in coastal zones, and are distributed by complex local hydrographic conditions thus enhancing the species sensitivity levels, which may lead to changes in their geographical distribution limits as has been already documented for other locations (Teixeira et al., 2012). An oceanographic campaign was undertaken in March 2013, considering three stations along a depth transect. The two shallowest stations (3 and 4) are situated on the inner continental shelf at 80 and $100 \mathrm{~m}$ depth respectively (Fig. 1). The deepest station (5) is situated on the outer continental shelf at $140 \mathrm{~m}$ depth, where hypoxic conditions have been recorded (Fig. 1). Records of the location and depth of each sampling station were made using a GPS Echo-sounder Garmin.

\section{Sampling and processing}

Water column temperature, salinity and dissolved oxygen (DO) were measured using a CTDO Seabird 19 Plus. In addition, discrete water samples at different depths were collected with Niskin bottles for DO. Samples for meiofauna and sediment parameters were collected using a gravity corer with a $50 \mathrm{~mm}$ internal diameter. Five sediment samples were collected in each station for organic matter content $(\mathrm{OM})$, grain size, redox potential $\left(\mathrm{Eh}_{\mathrm{NHE}}\right)$, chlorophyl- $a(\mathrm{Chl}-a)$, phaeopigment (Phaeop), carbon stable isotope ratio $\left(\delta^{13} \mathrm{C}\right)$, total organic carbon (TOC) and carbon-nitrogen ratio $(\mathrm{C}: \mathrm{N})$ analyses. From each station two replicates for meiofauna were sub-sampled with Plexiglas tubes 30 $\mathrm{mm}$ internal diameter. To study the vertical distribution the first six centimeters of sediment column were examined. In order to achieve these the tubes were processed and subdivided into three horizontal layers $(0-2,2-4$ and 4-6 cm). All samples were fixed in 4\% formalin buffered with sodium borate. A $63 \mu \mathrm{m}$ mesh sieve was used and meiofauna were extracted using the 

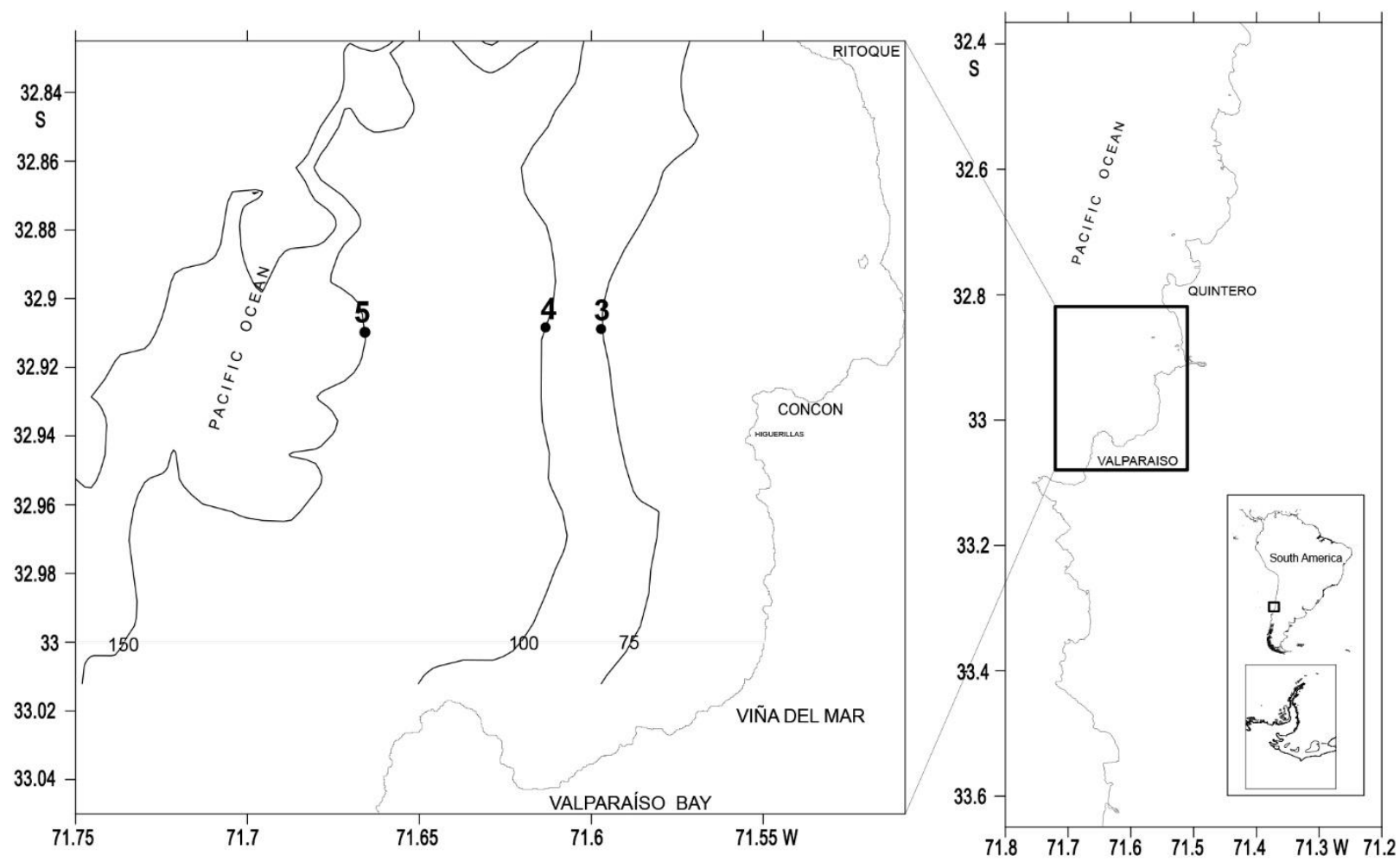

Figure 1. Study site showing the oceanographic sampling stations.

methodology of resuspension-decantation (Wieser, 1960) after sonicating the sediment for $10 \mathrm{~s}$ (Thiel et al., 1975). The efficiency of this method has been reported by Murrell \& Fleeger (1989). All meiofaunal individuals were sorted, identified into major taxa and counted under a stereo microscope Nikon Eclipse E 200. Abundance was expressed as individuals per 10 $\mathrm{cm}^{2}$.

\section{Laboratory analyses}

The samples for DO were analyzed by the Winkler method as modified from Carpenter's technique (Knap et al., 1993), and microtitrated with a DOSIMAT. Total organic matter (TOM) in marine sediments was determined at $2 \mathrm{~cm}$ intervals by loss of weight on ignition at $475-500^{\circ} \mathrm{C}$ for $4 \mathrm{~h}$ (Byers et al., 1978). Carbon stable isotope content $\left(\delta^{13} \mathrm{C}\right)$ was analyzed by mass spectrometry (VG Micromass 602C equipment) at the Environment Isotopes Laboratory of the CCHEN (Chile). The $\delta^{13} \mathrm{C}(\%)$ values are relative to the Pee Dee Belemnite (PDB) Standard (Silva et al., 2011). In order to estimate the contribution of allochthonous organic matter (Alloch) in the study area, we used $-26.9 \%$ as terrestrial reference value, and we used for marine sediment an average value obtained from samples in the study area $(-21.7 \%)$, which were consistent with those reported by Silva et al. (2011).
The total organic carbon (TOC) and total nitrogen (TN) content of the surface sediments were analyzed on freeze-dried and homogenized sample material. Measurements were made in a $\mathrm{CHN}$ elemental analyzer (Flash EA 2000) after acidification treatment with $1 \mathrm{~N}$ $\mathrm{HCl}$. Redox potential $\left(\mathrm{Eh}_{\mathrm{NHE}}\right)$ was measured at $2 \mathrm{~cm}$ intervals in the laboratory using a platinum standard combination electrode with a calomel internal reference (SGTM, Mettler Toledo). The total sulfides content in was determined colorimetrically according to method of Cline (1969). Chl- $a$ and phytopigment degradation products (i.e., phaeopigments) were extracted from duplicate subsamples of wet sediment ( $c a .1 \mathrm{~g})$ using $90 \%$ acetone. After $24 \mathrm{~h}$ of darkness at $4{ }^{\circ} \mathrm{C}$, the samples were sonicated for $5 \mathrm{~min}$, centrifuged at 3,000 rpm $(1,000 \mathrm{~g})$ for $10 \mathrm{~min}$, and extracts were fluorometrically analyzed for Chl- $a$ and Phaeop content. Chl$a$ and Phaeop values were obtained before and after acidification with $1 \mathrm{~N} \mathrm{HCl}$, respectively, according to Lorenzen's method, as described in Parsons et al. (1984), where the volume of water is substituted by the dry weight (DW) of the sediment expressed in gram. Values were thus expressed, corrected for porosity as measured by the water content, as $\mu \mathrm{g}$ Chl- $a \mathrm{~g}^{-1} \mathrm{DW}$. This was obtained after drying duplicate sediment subsamples $(\mathrm{ca} .1 \mathrm{~g})$ at $105^{\circ} \mathrm{C}$ for $20 \mathrm{~h}$. Chloroplast pigment equivalents (CPE) is the sum of Chl- $a$ and Phaeop, which is an indicator of fresh organic matter 
(Pfannkuche \& Soltwedel, 1998). Particle grain size data were analyzed following Folk and Ward scale (Folk, 1980; Blott \& Pye, 2001).

\section{Data analyses}

Kruskal-Wallis test were used to detect differences in meiofauna mean abundance between sites. The correlations between biological and sediment variables were calculated using Spearman correlation analyses. All tests were performed using the Statistica software package version 7.0. In addition, Canonical correspondence analysis (CCA) was performed with the software PAST 3.01 (Hammer et al., 2001). CCA was applied to relate the set of environmental parameters and meiofaunal groups among sampling stations, as suggested by Jongman et al. (1987).

\section{RESULTS}

\section{Sediment properties}

Details of environmental parameters are shown in Table 1. Bottom water DO concentrations showed a decreasing pattern with depth with a mean of $2.42 \pm$ $0.29 \mathrm{~mL} \mathrm{~L}^{-1}$. Similar spatial trends were observed for Chl- $a$, Alloch and $\delta^{13} \mathrm{C}$ variables with mean values of $10.9 \pm 1.35 \mu \mathrm{g} \mathrm{g}^{-1}, 41.03 \pm 22.95(\%)$ and $-23.83 \pm 1.19$ $\%$, respectively. The opposite pattern was observed for organic matter content $(\%)$ with a higher proportion at station 5 in the $0-2$ and 2-4 cm sediment layers. The same situation was recorded for $\operatorname{Eh}_{\mathrm{NHE}}(\mathrm{mV})$ with the highest values recorded in the 2-4 and $4-6 \mathrm{~cm}$ sediment layers. The values observed for these parameters indicate the low oxidation of sediments at the study site. The rest of sediment variables showed spatial variability without a clear pattern with mean values of $15.23 \pm 4.44 \mathrm{mg} \mathrm{g}^{-1}$ for TOC, $12.21 \pm 1.11$ molar for $\mathrm{C}: \mathrm{N}, 22.97 \pm 8.28 \mu \mathrm{g} \mathrm{g}^{-1}$ for Phaeop, and $33.88 \pm 9.41$ $\mu \mathrm{g} \mathrm{g}^{-1}$ for CPE. The sediment composition (e.g., grain size) was characterized by a higher proportion of mud $(>70 \%)$ and lower content of sand $(<28 \%)$ in all stations. However, the sediment parameters did not exhibit significant differences among stations in the study area (Kruskal-Wallis test $P>0.05$ ).

\section{Taxonomic composition and abundance}

A total of 40 taxa (different morphotypes) were recognized in the study site belonging to nine upper metazoan meiofaunal groups. Nematodes were the dominant group contributing with more than $95 \%$ of relative abundance at all sites (Table 2). In this group 22 taxa were distinguished belonging to 14 familias. Copepoda and Acari with 6 and 9 taxa respectively were the next most important groups, but they did not exceed 3 and $6 \%$ of total relative abundance, respectively. The rest of taxa: nauplii larvae, gastrotrichs, kinorhynchs, polychaetes, oligochaetes and cumaceans exhibited low relative abundances (below 1\%) and scarce taxonomic representation. The main taxonomic groups are show in Fig. 2. Details of taxonomic composition and hits relative abundance are show in Annex 1.

Meiofaunal abundance decreased with the depth ranging from $2,218 \pm 643$ ind $10 \mathrm{~cm}^{-2}$ at stn. 3 to 1,592 \pm 148 ind $10 \mathrm{~cm}^{-2}$ at stn. 4 . No significant differences were observed between stations (Kruskal-Wallis test, $\left.H_{2}=1.21, P>0.05\right)$. Nematode abundances reached maximum values at station 3 with 2,136 \pm 634 ind 10 $\mathrm{cm}^{-2}$, while the lowest abundances were recorded at stn. 4 with $1,528 \pm 138$ ind $10 \mathrm{~cm}^{-2}$ (Fig. 3a). Acari abundances were two to three orders of magnitude lower than nematodes, and were the second most abundant meiofaunal group, which ranged from $56 \pm 9$ ind $10 \mathrm{~cm}^{-2}$ at stn. 3 to $7 \pm 2$ ind $10 \mathrm{~cm}^{-2}$ at station 5 (Fig. 3b). Copepod abundances varied from 10 ind 10 $\mathrm{cm}^{-2}$ at stn. 4 and 5, to $5 \pm 0.98$ ind $10 \mathrm{~cm}^{-2}$ at stn. 3 . The rest of taxa recorded abundances lower than 2 ind $10 \mathrm{~cm}^{-2}$. Nematodes, nauplii larvae, copepods, acari and gastrotrichs were recorded at all stations. Contrasting, kinorhynchs were recorded at stn. 4 and 5, with higher abundances at the stn. $5\left(27 \pm 6\right.$ ind $\left.10 \mathrm{~cm}^{-2}\right)$. Cumaceans and oligochaetes were also recorded at station 4 , while polychaetes only at stn. 5 . These taxa always were recorded with very low abundances $(<1$ ind $10 \mathrm{~cm}^{-2}$ ).

\section{Vertical distribution}

Vertical distribution profiles of the major meiofaunal taxa are shown in Figure 4. The meiofauna vertical distribution varied in the three stations. Meiofaunal abundances decreased with the sediment depth and nematodes were the dominant group at each depth (>90\% of abundance) dictating the overall vertical distribution pattern for the whole community. The single exception to this trend was Acari. This group increased with sediment depth recording the highest density in the 4-6 cm layer with a mean of $19.3 \pm 14,9$ ind $10 \mathrm{~cm}^{-2}$. On the other hand, nauplii larvae recorded a density slightly lower at $4-6 \mathrm{~cm}$ layer $(3.79 \pm 4.13$ ind $\left.10 \mathrm{~cm}^{-2}\right)$ in comparison to $0-2 \mathrm{~cm}$ layer $(3.83 \pm 4.37$ ind $10 \mathrm{~cm}^{-2}$ ). The great majority of the taxa were concentrated in the $0-2 \mathrm{~cm}$ sediment layer. Even some groups such as kinorhynchs, cumaceans and polychaetes were not recorded in the lower layers, while copepods and gastrotrichs had a wider vertical distribution. Including all sites and sediment layers, the median proportion of specimens (relative abundance) recorded in the $0-2,2-4$ and $4-6 \mathrm{~cm}$ layers was $75.2 \%$, 
Table 1. Abiotic properties of three sampling stations off central Chile. Sedimentary parameters are given for the top 0-1 $\mathrm{cm}$ layer (means of 3 samples). TOC: total organic carbon; C:N: carbon-nitrogen ratio; Chl- $a$ : chlorophyll- $a$; Phaeop: phaeopigments; Eh: redox potential; TOM: total organic matter; $\delta^{13} \mathrm{C}$ : ratio of stable isotopes; CPE: chloroplast pigment equivalents; Alloch: allochthonous organic matter.

\begin{tabular}{lccc}
\hline & Station 3 & Station 4 & Station 5 \\
\hline Depth $(\mathrm{m})$ & 80 & 100 & 140 \\
Latitude & $32^{\circ} 54^{\prime} 31$ & $32^{\circ} 54^{\prime} 31$ & $32^{\circ} 54^{\prime} 31$ \\
Longitude & $71^{\circ} 35^{\prime} 44$ & $71^{\circ} 36^{\prime} 48$ & $71^{\circ} 38^{\prime} 57$ \\
Bottom water temperature $\left({ }^{\circ} \mathrm{C}\right)$ & 11.31 & 11.26 & 11.2 \\
Bottom water oxygen $\left(\mathrm{mL} \mathrm{L}^{-1}\right)$ & 2.73 & 2.37 & 2.16 \\
TOC $\left(\mathrm{mg} \mathrm{g}^{-1}\right)$ & 12.41 & 20.35 & 12.95 \\
C:N ratio $(m o l a r)$ & 12.79 & 12.91 & 10.93 \\
Chl $a\left(\mu \mathrm{g} \mathrm{g}^{-1}\right)$ & 12.28 & 10.84 & 9.59 \\
Phaeop $\left(\mu \mathrm{g} \mathrm{g} \mathrm{g}^{-1}\right)$ & 32.44 & 17.06 & 19.42 \\
$\mathrm{CPE}\left(\mu \mathrm{g} \mathrm{g}^{-1}\right)$ & 44.73 & 27.91 & 29.01 \\
Eh & & & \\
$\mathrm{NHE}(\mathrm{mV})$ & 56 & 27 & 33 \\
$\quad 2-2 \mathrm{~cm}$ & -26 & -32 & -44 \\
$\quad-4 \mathrm{~cm}$ & -68 & -76 & -107 \\
$4-6 \mathrm{~cm}$ & 15 & 17.2 & 1.15 \\
Sulfides $\left(\mathrm{mg} \mathrm{kg}^{-1}\right)$ & 84.4 & 72 & 93.6 \\
Mud $(\%)$ & 15.6 & 28 & 6.3 \\
Sand $(\%)$ & & & \\
TOM $(\%)$ & 6.1 & 7.6 & 7.7 \\
$\quad 0-2 \mathrm{~cm}$ & 6.5 & 7.7 & 8.4 \\
$2-4 \mathrm{~cm}$ & 6.4 & 6.8 & 6.5 \\
$4-6 \mathrm{~cm}$ & -24.8 & -24.2 & -22.5 \\
$\delta^{13} \mathrm{C}(\%)$ & 59.62 & 48.08 & 15.38 \\
Alloch $(\%)$ & & & \\
\hline
\end{tabular}

Table 2. Relative abundance (\%) of meiofaunal groups in the study area in different sediment layers $(0-2,2-4$ and $4-6 \mathrm{~cm})$. Nem: Nematoda, Cop: Copepoda, Nau: Nauplii, Pol: Polychaeta, Aca: Acari, Cum: Cumacea, Gas: Gastrotricha, Olig: Oligochaeta, Kin: Kinorhyncha

\begin{tabular}{lccccccccc}
\hline Station & Nem & Cop & Nau & Pol & Aca & Cum & Gas & Olig & Kin \\
\hline 3 & & & & & & & & & \\
$0-2 \mathrm{~cm}$ & 98.3 & 0.25 & 0.20 & - & 0.65 & - & 0.55 & - & - \\
$2-4 \mathrm{~cm}$ & 97.2 & - & 0.13 & - & 2.70 & - & - & - & - \\
$4-6 \mathrm{~cm}$ & 82.4 & 0.60 & 3.57 & - & 13.40 & - & - & - & - \\
Total & 96.3 & 0.23 & 0.55 & - & 2.54 & - & 0.35 & - & - \\
4 & & & & & & & & & \\
$0-2 \mathrm{~cm}$ & 97.6 & 0.78 & 0.66 & - & 0.11 & 0.06 & 0.17 & - & 0.61 \\
$2-4 \mathrm{~cm}$ & 95.9 & - & - & - & 4.10 & - & - & - & - \\
$4-6 \mathrm{~cm}$ & 72.4 & - & 1.60 & - & 25.20 & - & - & 0.79 & - \\
Total & 95.9 & 0.63 & 0.63 & - & 2.10 & 0.04 & 0.13 & 0.04 & 0.49 \\
5 & & & & & & & & & \\
$0-2 \mathrm{~cm}$ & 97.1 & 0.64 & - & 0.05 & - & - & 0.29 & - & 1.90 \\
$2-4 \mathrm{~cm}$ & 97.2 & 0.31 & 0.31 & - & 1.80 & - & 0.31 & - & - \\
$4-6 \mathrm{~cm}$ & 90.5 & - & 3.17 & - & 6.40 & - & - & - & - \\
Total & 97 & 0.57 & 0.12 & 0.04 & 0.41 & - & 0.29 & - & 1.60 \\
\hline
\end{tabular}

$18 \%$ and $6.8 \%$ respectively for the total meiofauna. Nevertheless, without considering the nematode abundances this proportion changed between stations.
At stn. 3 the higher proportion of specimens, 51.8\%, was concentrated at 4-6 cm sediment layer. At stn. 4 specimens were slightly more abundant at $0-2 \mathrm{~cm}$ 

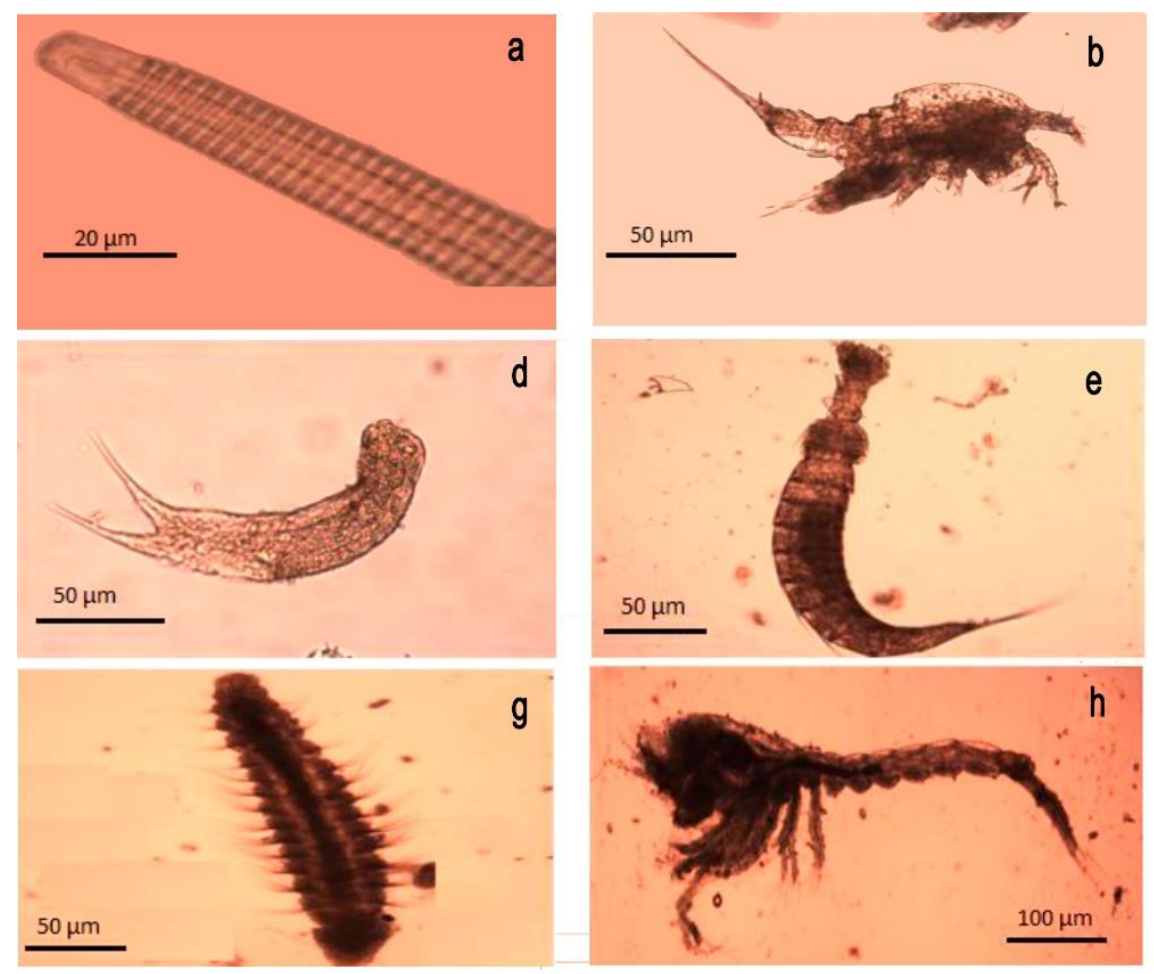
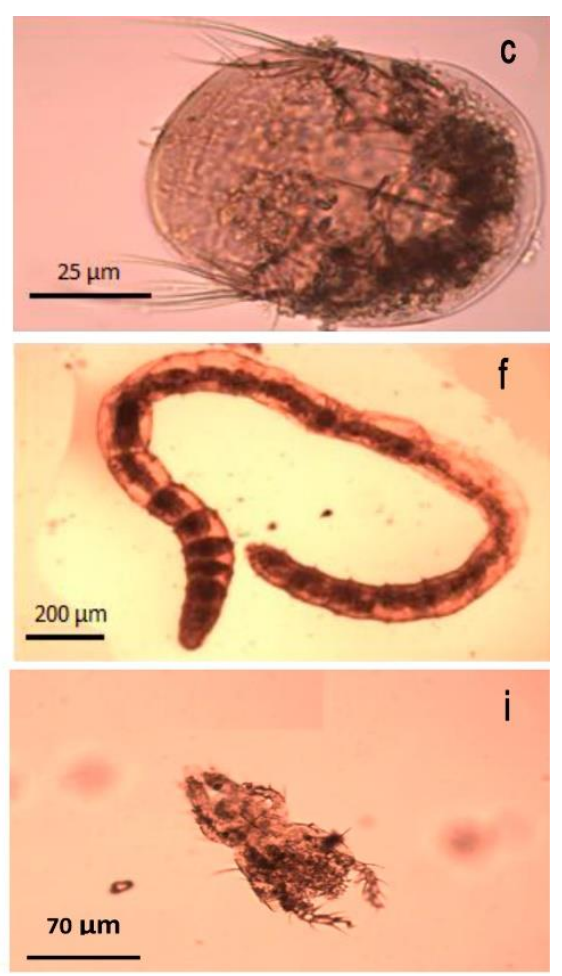

Figure 2. Light microscope photographs of meiofaunal taxa found at Valparaiso Bay. a) Nematoda, b) Copepoda, c) Nauplii, d) Gastrotricha, e) Kinorhyncha, f) Oligochaeta, g) Polychaeta, h) Cumacea, i) Acari.
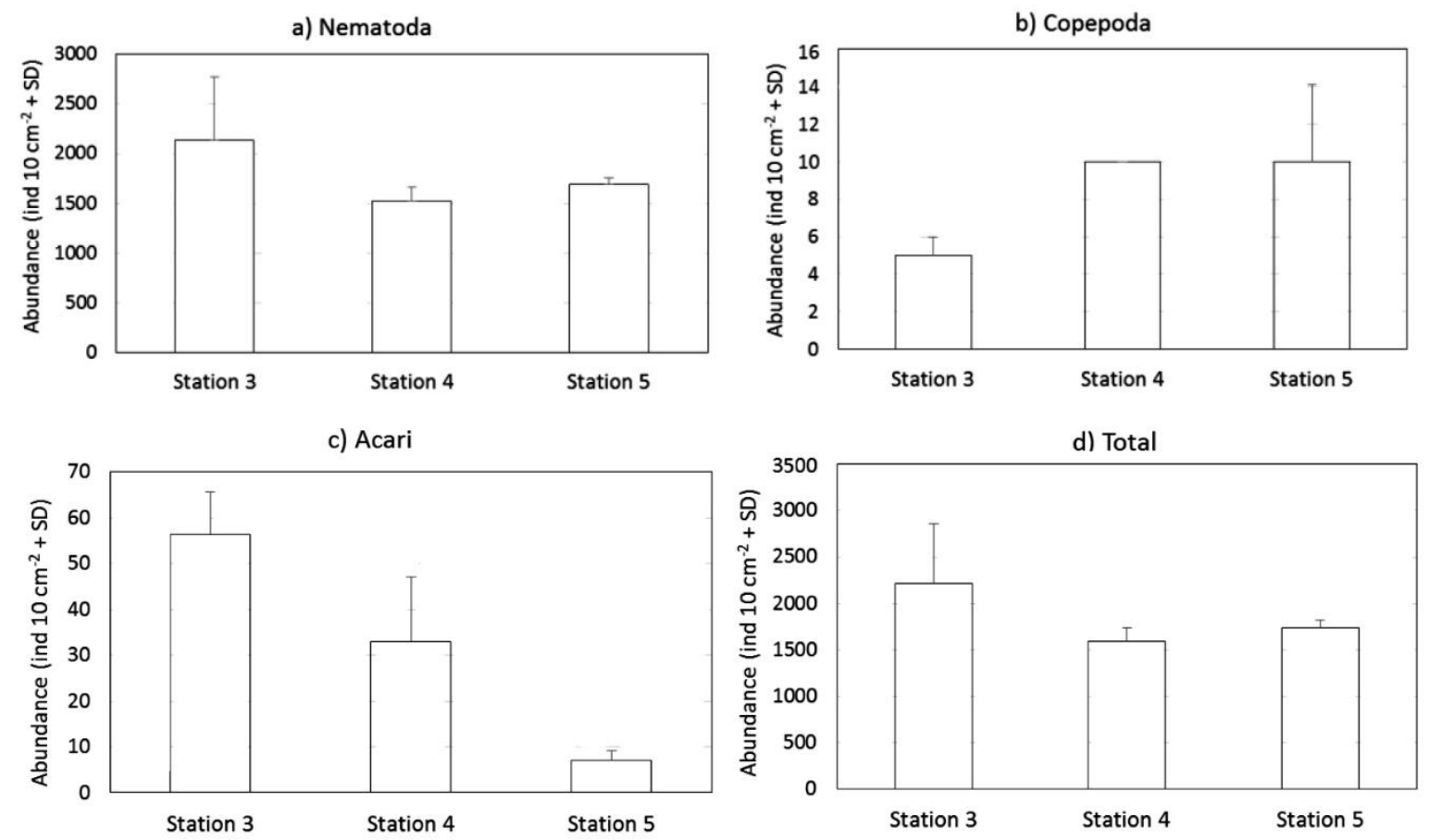

Figure 3. Meiofauna mean abundance in each sampling station. a) Nematoda, b) Copepoda, c) Acari, and d) Total meiofauna. Error bars indicate the standard deviation. 

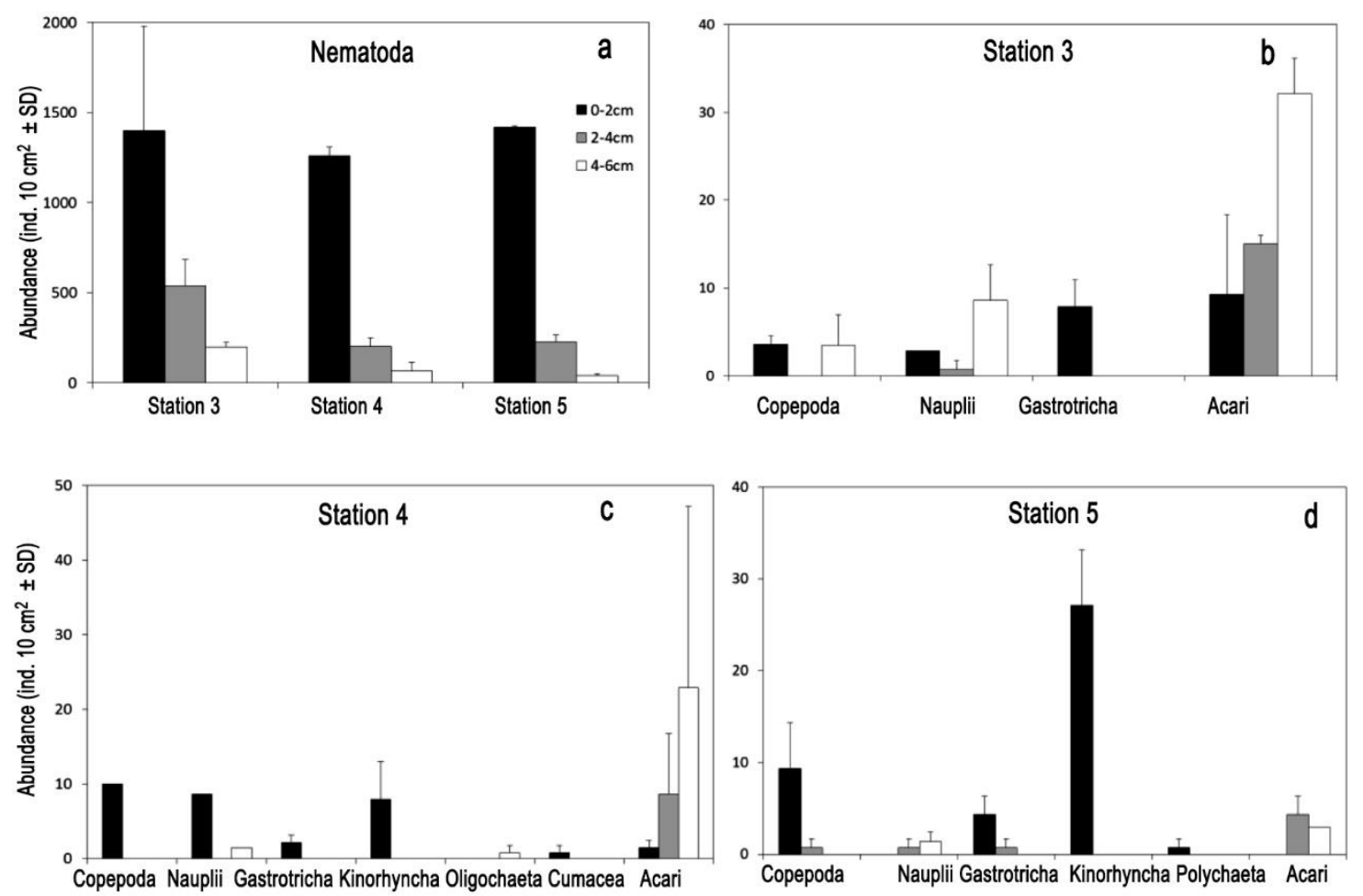

Figure 4. Mean abundance vertical distribution at 0-2, 2-4 and 4-6 cm sediment layers. a) Nematoda (all stations), b) Station 3, c) Station 4, and d) Station 5. Graphs b, c and d: nematodes excluded.

(47.7\%), while that at stn. 5 the distribution was closer to the overall pattern (nematodes included) with $79.4 \%$ at 0-2 $\mathrm{cm}$ sediment layer.

\section{Relationships between environmental parameters and meiofauna}

The results of the CCA are shown in Fig. 5. Only the five environmental variables that explained most of the variance were included in the analysis (i.e., Depth, $\mathrm{C} / \mathrm{N}$, Allochthonous OM, TOC and Redox potential). When the abundance of the dominant meiofaunal groups is related to the environmental variables the first CCA axis eigenvalues accounted for $89.8 \%$ of the total variance and the second CCA axis eigenvalues accounted for $10.3 \%$ of the explained variance. This suggests a relatively good dispersal of the biological data along the different axis in both analyses. For the meiofauna composition, the first axis reveals gradients influenced by allochthonous content of organic matter $(\mathrm{r}=0.99), \mathrm{C} / \mathrm{N}$ ratio $(\mathrm{r}=0.96)$ and depth $(\mathrm{r}=-0.85)$, while the second axis reflects a gradient influenced by TOC $(r=0.97)$ and redox potential $(r=-0.84)$. In terms of meiofauna composition, Nematoda was the dominant group in all stations, but Cumacea and Oligochaeta were more representatives in stn. 4, while Polychaeta and Kinorhyncha in stn. 5.

\section{DISCUSSION}

\section{Environmental parameters}

Meiofaunal assemblages at central Chile are influenced by the Equatorial Subsurface Water (ESSW), which flows poleward over the shelf and upper slope (Sellanes $\&$ Neira, 2006). This water mass has low oxygen concentrations and is the source of coastal upwelling that drives high primary production (Fossing et al., 1995; Daneri et al., 2000) and generates the food supply to the seabed (Gutiérrez et al., 2000). The $\mathrm{C} / \mathrm{N}$ ratio value recorded in this study was 10.93 on the outer continental shelf. This value indicates that accumulated organic matter has been decomposed from nitrogen compounds (Scheffer \& Schachtschabel, 1984). C/N ratio values in the first few centimeters of sediment were similar to values found off Peru with 9.8 (Levin et al., 2002) and higher in comparison to values recorded in Concepción Bay by Veit-Köhler et al. (2009) and Neira et al. (2013) with 7.8 and 7.06, respectively. TOC contents in the study area were similar to those recorded by Neira et al. (2013) off Concepción at $122 \mathrm{~m}$ depth with $46.91 \mathrm{mg} \mathrm{g}^{-1}$. In comparison with other upwelling areas, TOC values were also similar to those reported at the Arabian Sea (14.3-54.3 $\mathrm{mg} \mathrm{g}^{-1}$ ) (Smallwood \& Wolff, 2000), but lower that those recorded off Peru 


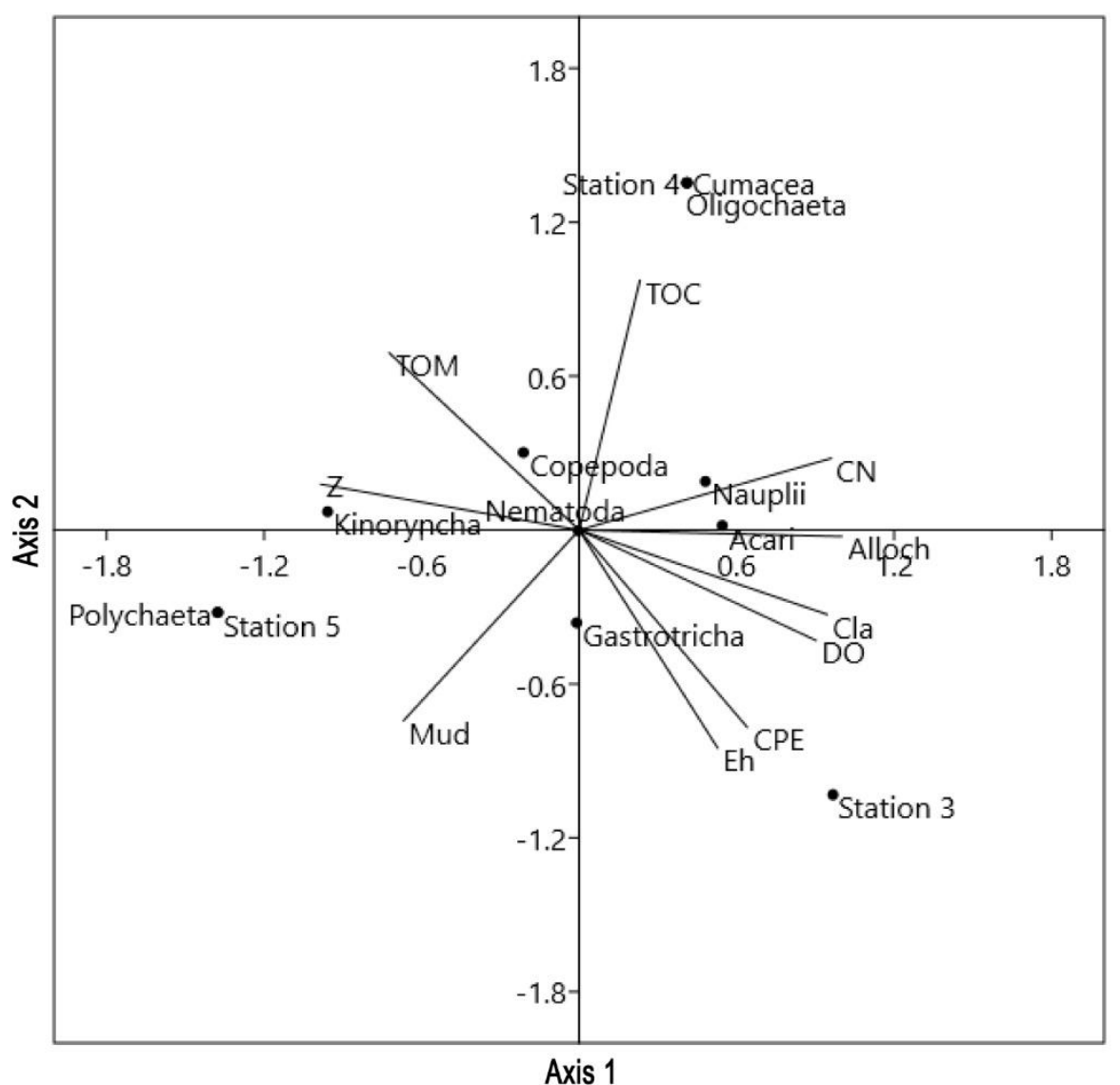

Figure 5. Canonical correspondence analysis displaying the meiofaunal groups in relation to environmental variables that best explain the abundance distribution among stations. Relationships were significant $(P<0.05)$.

(>205 $\mathrm{mg} \mathrm{g}^{-1}$ ) (Neira et al., 2001b). The concentrations of Chl- $a$ and Phaeop in the current research were lower than found in studies made by Neira et al. (2013) (124.62 and $196.76 \mu \mathrm{g} \mathrm{g}^{-1}$, respectively). However, they were higher than those recorded by Neira et al. (2001b) $\left(4.30 \mu \mathrm{g} \mathrm{g}^{-1}\right)$ on the continental slope off Peru.

\section{Meiofauna}

It is known that habitat heterogeneity due to physical or chemical properties of the sediment would be an important factor controlling the meiobenthos community structure (Gooday et al., 2010). In physical terms the grain size variations recorded were not important as correlations with meiofaunal groups were not found. However in chemical terms in addition to the DO, content of organic matter, Chl- $a$ and CPE decreased with depth and significant correlations were found between meiofauna abundance and organic content $(\mathrm{C} / \mathrm{N}$, Allochthonous organic matter and TOC), depth and redox potential sediment parameters. For instances, the organic matter content, Chl- $a$ and DO were positively correlated with meiofauna abundance in Concepción Bay (Neira et al., 2013; Sellanes et al., 2003; Sellanes \& Neira, 2006; Veit-Köhler et al., 2009). In our study area, nematodes constitute more than $95 \%$ of total meiofauna abundances, being considered the taxon that can best cope with low oxygen conditions and high organic matter content on the sediments. In fact, only meiofauna is well adaptated to low oxygen in the suboxic to anoxic layers (Braeckman et al., 2013). In this sense the deeper vertical distribution of Acari and nauplii larvae in some sedimentos layers, where negative values of redox potential were recorded, would demonstrate this kind adaptation in the current study.

Table 3 shows the meiofaunal abundance from different locations with similar characteristics to Valparaíso Bay. The total abundances of nematodes at the three stations were slightly higher than those reported by Sellanes et al. (2003) and Veit-Köhler et al. (2009) for the continental shelf off central Chile. Mean abundances recorded on the inner and outer continental shelf in the current study (Fig. 3d) were similar to those described by De Bovée et al. (1996), where meiofaunal 
Table 3. Comparison of meiofaunal abundances among areas sharing similar characteristics with Valparaíso Bay and/or adjacent continental shelf. Abundances reported as ind $10 \mathrm{~cm}^{-2}$.

\begin{tabular}{lclccl}
\hline Zone & Depth $(\mathrm{m})$ & Environment & $\begin{array}{c}\text { Nematode } \\
\text { abundance }\end{array}$ & $\begin{array}{c}\text { Total } \\
\text { meiofauna }\end{array}$ & Reference \\
\hline Arabian Sea & 400 & Upwelling & 1.700 & - & Cook et al. (2000) \\
\hline Southeast continental shelf of India & $75-100$ & Upwelling & - & 700 & Ansari et al. $(2012)$ \\
& $100-150$ & & & 800 & Neira et al. (2001b) \\
\hline Continental shelf Perú $\left(12^{\circ} \mathrm{S}\right)$ & 305 & OMZ & $1.502 \pm 430$ & $1.517 \pm 431$ & \\
\hline Atacama Trench & 1.050 & Bathyal depths & $498 \pm 157$ & $550 \pm 186$ & Danovaro et al. (2002) \\
& 7.800 & Hadal depths & $5.072 \pm 2.344$ & $6.378 \pm 3,061$ & \\
\hline Continental shelf central Chile & 88 & OMZ & $1.193-2.417$ & $1.202-2.433$ & Sellanes et al. (2003) \\
& 120 & OMZ & $738-1.268$ & $895-1.318$ & \\
\hline Continental shelf central Chile & 126 & OMZ & $1.555-3.077$ & $1.577-3.229$ & Veit-Köhler et al. (2009) \\
\hline Continental shelf, Valparaiso Bay & 80 & Seasonal hypoxia & $2.136 \pm 633$ & $2.218 \pm 643$ & This study \\
& 100 & Seasonal hypoxia & $1.528 \pm 138$ & $1.592 \pm 148$ & \\
\hline
\end{tabular}

densities ranged between 1.000 and 2.000 ind $10 \mathrm{~cm}^{-2}$ from subtidal muddy environments. It is important to note that the study area is influenced by a seasonal hypoxia with DO concentrations about $2.34 \mathrm{~mL} \mathrm{~L}^{-1}$, while low oxygen levels $\left(<0.5 \mathrm{~mL} \mathrm{~L}^{-1}\right)$ have been documented at Concepción bay. Indeed, low oxygen levels have been registered on the continental shelf off Peru (Neira et al., 2001b) and in the Arabian Sea (Cook et al., 2000), where nematodes abundance appear to be similar to our study. On the other hand, the number of taxonomic groups found in this study ( 9 taxa) was lower than observed for Concepción Bay by Sellanes et al. (2003) with 13 taxa and for Chiloé, southern Chile by Veit-Köhler et al. (2009) where 16 taxa were recorded. This minor presence of taxonomic groups could be explained by nematode dominance (total abundance $>95 \%$ ) (Table 2) or due to minor number of samples considered. Levin et al. (1991) and Neira et al. (2001b) argue that these organisms are highly successful in sediments rich on organic matter and with low dissolved oxygen concentrations. In this respect the organic matter content averaged $7.13 \%$ in surficial sediments $(0-2 \mathrm{~cm})$ while hypoxic conditions were recorded (Table 2). These authors affirm that the oxygen could control the meiofauna composition at level of major taxonomic groups within the $\mathrm{OMZ}$ zones.

Meiofauna vertical distribution is mainly controlled by food deficiency and oxygen availability with around $90 \%$ of total meiofauna being concentrated between 0 $5 \mathrm{~cm}$ sediment layers (Giere, 2009). In our study, 93\% of total meiofauna was concentrated in the $0-4 \mathrm{~cm}$ sediment layer (Fig. 4a) which could be an adaptive response related to their trophic strategies. However our results suggest that this vertical distribution pattern would be mainly determined by higher concentrations of fresh organic content in the surficial sediment layers. It is well know that nematodes have a wide variety of trophic strategies from carnivore predators to bacterivorous guilds (Wieser, 1960; Neira et al., 2013) and they are dominants in all type of sediments inhabiting in both oxidized and reduced conditions. However a trophic guild classification was not made for this study, although some similar trophic strategies to those reported by Neira et al. (2013) for Concepción could be found. In addition, nematodes dominance is thought to be the result of the capacity to tolerate low oxygen conditions and the reduced predation pressure/competition as a result of the higher sensitivity of other benthic organisms to hypoxia/anoxia (Neira et al., 2001a, 2001b; Levin et al., 2002). The results recorded in the current study showed that the vertical distribution of nematode abundances changed mainly between 2-4 and 4-6 cm sediment layers (Table 2). This minor relative abundance that was clearly observed at station 4, where a higher proportion of sand was recorded, could be explained by the higher relative abundance of Acari and nauplii at 4-6 cm layer. This could be suggesting a nematode response to competition with other taxa or sensitivity to redox potential conditions of the sediments as revealed by CCA.

Gastrotrichs, kinorhynchs and copepods concentrated their abundances in the first centimeters of the sediment. The vertical distribution in these groups could be explained by their sensitivity to low levels of DO, their morphology and body size (Giere, 2009). In the case of copepods they could be unable to easily adapt to interstitial environments. A different vertical distribution pattern was observed for nauplii and Acari. Nauplii did not show a higher abundance in surficial sediment layers, with wide vertical variation between 
stations. Contrastingly, Acari were mainly distributed in sub-surficial sediment layers $(2-4$ and $4-6 \mathrm{~cm})$ at all stations. Vertical distribution pattern for nauplii and Acari could be associated to predation pressure and bioturbation in surficial sediment where the competition for habitat and fresh food supply is very high. For instances, a similar vertical distribution pattern also have been recorded for Acari (Acarina) in seamounts (Zeppilli et al., 2013).

It is known that oceanographic characteristics along the continental margin off central Chile are influencing the spatial distribution of mega-, macro- and meiobenthic communities (e.g., Palma et al., 2005; Quiroga et al., 2009; Sellanes \& Neira, 2006). In fact, the effects of upwelling under normal, ENSO and OMZs conditions have been well documented off central Chile (Neira et al., 2013; Sellanes et al., 2003; Sellanes \& Neira, 2006), the continental shelf off Peru (Neira et al., 2001b; Levin et al., 2002) and in the Arabian sea (Cook et al., 2000; Gooday et al., 2000). From these studies, the organic matter quality and oxygen availability have been the main variables explaining the meiofauna community structure. In the current study the organic content of the sediments comes from primary production together to redox potential and depth were the only environmental variables explaining the distribution of meiofauna groups, while oxygen levels were not correlated. The composition, abundance and distribution of the meiobenthic community provided in this study represents a non-ENSO condition and can be useful as a baseline for future descriptions of this relevant oceanographic phenomena, which has already been confirmed for the South Pacific Ocean by 2015 (National Wheather Service, 2014). Time series studies are suggested to assess the ecological response of these assemblages to conditions before mentioned and to another such as OMZ and upwelling seasonal changes.

\section{ACKNOWLEDGEMENTS}

Authors wish thank to Francisco Gallardo for his field work assistance. Williams Caballero thanks to Meioscool International Workshop 2013 organization and Universidad of Valparaíso for the financial support to attend to Meioscool International Workshop held in Brest, France. Authors also thank to Benjamin Ganga for the statistical analyses support and Carlos Neira (Scripps, UCSD) for his comments and assistance for improving this manuscript. This research was funded by Fondecyt 11121487 grant from National Science and Technology Commission belonging to the Chilean Education Ministry.

\section{REFERENCES}

Andrade, H. 1986. Observaciones biológicas sobre invertebrados demersales de la zona central de Chile. In: P. Arana (ed.). La pesca en Chile, Universidad Católica de Valparaíso, Ediciones Universitarias, Valparaíso, pp. 51-56.

Andrade, H. 1987. Distribución batimétrica y geográfica de macro-invertebrados del talud continental de Chile central. Cienc. Tecnol. Mar, 11: 61-94.

Andrade, H., S. Gutiérrez \& A. Salinas. 1986. Efectos del vertimiento de desechos orgánicos no tratados sobre la macroinfauna bentónica de un sector de la bahía de Valparaíso (Chile). Cien. Tecnol. Mar, 10: 21-49.

Ansari, K.G.M.T., P.S. Lyla \& S.A. Khan. 2012. Faunal composition of metazoan meiofauna from the continental shelf of India. Indian J. Geomar. Sci., 41(5): 457-467.

Arntz, W., J. Tarazona, V.A. Gallardo, L. Flores \& H. Salzwedel. 1991. Benthos communities in oxygen deficient shelf and upper slope areas of the Peruvian and Chilean Pacific coast, and changes caused by El Niño. Geol. Soc., 58: 131-154.

Asencio, G., E. Clasing, C. Herrera, R. Stead \& J.M. Navarro. 1995. Larval development of Amphiascopsis cinctus Claus, 1866 (Harpacticoida: Diosaccidae) and Laophonte parvula Sars, 1908 (Harpacticoida: Laophontidae). Rev. Chil. Hist. Nat., 68: 283-301.

Bello, M. \& J. Maturana. 2004. Condiciones oceanográficas frente a Valparaíso durante la fase fría del ciclo ENOS 1997-2000. In: S. Avaria, J. Carrasco, J. Rutllant \& E. Yáñez (eds.). El Niño-La Niña 19972000, sus efectos en Chile. Comité Oceanográfico Nacional, Valparaíso, pp. 29-42.

Blott, S.J. \& K. Pye. 2001. Gradistat: a grain size distribution and statistics package the analysis of unconsolidated sediments. Earth Surf. Process. Landforms, 26(11): 1237-1248.

Boyd, S.E., H.L. Rees \& C.A. Richardson. 2000. Nematodes as sensitive indicators of change at dredged material disposal sites. Estuar. Coast. Shelf Sci., 51: 805-819.

Braeckman, U., J. Vanaverbeke, M. Vincx, D. van Oevelen \& K. Soetaert. 2013. Meiofauna metabolism in suboxic sediments: currently overestimated. PLoS ONE 8(3): e59289. doi:10.1371/journal.pone.0059 289.

Brandhorst, W. 1971. Condiciones oceanográficas estivales frente a la costa de Chile. Rev. Biol. Mar., 14(3): 45-84.

Byers, S.C., E.L. Mills \& P.L. Stewart. 1978. A comparison of methods of determining organic carbon in marine sediments, with suggestions for a standard method. Hydrobiologia, 58(1): 43-47. 
Chen, G.T., R.L. Herman \& M. Vincx. 1999. Meiofauna communities from the Straits of Magellan and the Beagle Channel. Sci. Mar., 63(Suppl. 1): 123-132.

Cline, J.D. 1969. Spectrophotometric determination of hydrogen sulfide in natural waters. Limnol. Oceanogr., 14: 454-458.

Cook, A.A., P.J. Lambshead, L.E. Hawkins, N. Mitchell \& L.A. Levin. 2000. Nematode abundance at the oxygen minimum zone in the Arabian Sea. Deep-Sea Res. II, 47: 75-85.

Cowie, G.L. 2005. The biogeochemistry of Arabian Sea surficial sediments: a review of recent studies. Prog. Oceanogr., 65: 260-289.

Daneri, G., V. Dellarossa, R. Quiñones, B. Jacob, P. Montero \& O. Ulloa. 2000. Primary production and community respiration in the Humboldt Current System off Chile and associated oceanic areas. Mar. Ecol. Prog. Ser., 197: 41-49.

Danovaro, R., C. Gambi \& N. Della-Croce. 2002. Meiofauna hotspot in the Atacama Trench, eastern South Pacific Ocean. Deep-Sea Res. I, 49(5): 843-857.

De Bovée, F., P.O.J. Hall, S. Hulth, G. Hulthe, A. Landen \& A. Tengberg. 1996. Quantitative distribution of metazoan meiofauna in continental margin sediment of the Skaggerak (Northeastern North Sea). J. Sea Res., 35(1): 189-197.

Fenchel, T.M. 1978. The ecology of micro- and meiobenthos. Annu. Rev. Ecol. Syst., 9: 99-121.

Folk, R.L. 1980. Petrology of sedimentary rocks. Hemphill Publishing Company, Austin, 181 pp.

Fossing, H., V.A. Gallardo, B.B. Jørgensen, M. Hüttel, L.P. Nielsen, H. Schulz et al. 1995. Concentration and transport of nitrate by the mat-forming sulphur bacterium Thioploca. Nature, 374: 713-715.

Fuenzalida, R., W. Schneider, J. Garcés-Vargas, L. Bravo \& C. Lange. 2009. Vertical and horizontal extension of the oxygen minimum zone in the eastern South Pacific Ocean. Deep-Sea Res. II, 56: 992-1003.

Gallardo, V.A., M. Palma, F.D. Carrasco, D. Gutiérrez, L.A. Levin \& J.I. Cañete. 2004. Macrobenthic zonation caused by the oxygen minimum zone on the shelf and slope off central Chile. Deep-Sea Res. II, 51: 2475-2490.

Gambi, C., A. Vanreusel \& R. Danovaro. 2003. Biodiversity of nematode assemblages from deep-sea sediments of the Atacama Slope and Trench (South Pacific Ocean). Deep-Sea Res. I, 50: 103-117.

George, K.H. \& H.K. Schmink. 1999. Sublittoral Harpacticoida (Crustacea, Copepoda) from the Magellan Straits and the Beagle Channel (Chile).
Preliminary results on abundances and generic diversity. Sci. Mar., 63 (Suppl. 1): 133-137.

Gerlach, S.A. 1971. On the importance of marine meiofauna for benthos communities. Oecologia, 6: 176190.

Giere, O. 2009. Meiobenthology. The microscopic fauna in aquatic sediments. Springer Verlag, Berlin, 538 pp.

Gooday, A.J., J.M. Bernhard, L.A. Levin \& S.B. Suhr. 2000. Foraminifera in the Arabian Sea oxygen minimum zone and other oxygen-deficient settings: taxonomic composition, diversity, and relation to metazoan faunas. Deep-Sea Res. II, 47: 25-54.

Gooday, A.J., B.J. Bett, E. Escobar, B. Ingole, L.A. Levin, C. Neira, A.V. Raman \& J. Sellanes. 2010. Habitat heterogeneity and its influence on benthic biodiversity in oxygen minimum zones. Mar. Ecol., 31: 125-147.

Gooday, A.J., LA Levin, A. Aranda da Silva, B.J. Bett, G.L. Cowie, D. Dissard, et al. 2009. Faunal responses to oxygen gradients on the Pakistan margin: a comparison of foraminiferans, macrofauna and megafauna. Deep-Sea Res. II, 56: 488-502.

Gutiérrez, D., V.A. Gallardo, S. Mayor, C. Neira, C. Vasquez, J. Sellanes, M. Rivas, A. Soto, F.D. Carrasco \& M. Baltazar. 2000. Effects of dissolved oxygen and fresh organic matter on macrofaunal bioturbation potential in sublittoral bottoms off central Chile, during the 1997-1998 El Niño. Mar. Ecol. Prog. Ser., 202: 81-99.

Gutiérrez, D., A. Sifeddine, J.L. Reyss, G. Vargas, F. Velazco, R. Salvatecci et al. 2006. Anoxic sediments off Central Peru record interannual to multidecadal changes of climate and upwelling ecosystem during the last two centuries. Adv. Geosci., 6: 119-125.

Hammer, O., D. Harper \& P. Ryan. 2001. PAST: Palaeontological statistics, versión 0.96. Palaeontol. Electron., 4(1): $9 \mathrm{pp}$.

Jongman, R., C. Ter Braak \& O. van Tongeren. 1987. Data analysis in community and landscape ecology. PUDOC, Wageningen, 299 pp.

Knap, A., R. Michaels, R. Dow, K. Johnson, J. Gundersen, A. Sorensen, F. Close, M. Howse, N. Hammer, A. Bates \& T. Waterhouse. 1993. Bermuda Atlantic timeseries study methods manual (Version 3). Bermuda Biological Station for Research, U.S. JGOFS, 108 pp.

Lee, M.R., J.A. Correa \& R. Seed. 2006. A sediment quality triad assessment of the impact of copper mine tailings disposal on the littoral sedimentary environment in the Atacama region of northern Chile. Mar. Pollut Bull., 52: 1389-1395.

Lee, M.R. \& J.A. Correa. 2007. An assessment of the impact of copper mine tailings disposal on meiofaunal 
assemblages using microcosm bioassays. Mar. Environ. Res., 64(1): 1-20.

Lee, M.R. \& M. Riveros. 2012. Latitudinal trends in the species richness of free-living marine nematode assemblages from exposed sandy beaches along the coast of Chile (18-42 ${ }^{\circ}$ ). Mar. Ecol., 33(3): 317-325.

Levin, L.A. 2003. Oxygen minimum zone benthos: adaptations and community response to hypoxia. Oceanogr. Mar Biol. Annu. Rev., 41: 1-45.

Levin, L.A., C.L. Huggett \& K.F. Wishner. 1991. Control of deep-sea benthic community structure by oxygen and organic matter gradients in the Eastern Pacific Ocean. J. Mar. Res., 49: 763-800.

Levin, L., D. Gutierrez, A. Rathburn, C. Neira, J. Sellanes, P. Muñoz, V. Gallardo \& M. Salamanca. 2002. Benthic processes on the Peru margin: a transect across the oxygen minimum zone during the 1997-1998 El Niño. Prog. Oceanogr. 53: 1-27.

Moreno, R.A., R.D. Sepúlveda, E.I. Badano, S. Thatje, N. Rozbaczylo \& F.D. Carrasco. 2008. Subtidal macrozoobenthos communities from northern Chile during and post El Niño 1997-1998. Helgoland Mar. Res., 62(1): 45-55.

Murrell, M.C. \& J.W. Fleeger. 1989. Meiofauna abundance on the Gulf of Mexico continental shelf affected by hypoxia. Cont. Shelf Res., 9(12): 10491062.

National Weather Service. 2014. National Centers of Environmental Prediction. [http://www.ncep.noaa. gov]. Reviewed: 20 December 2013.

Neira, C., J. Sellanes, A. Soto, D. Gutiérrez \& V. Gallardo. 2001a. Meiofauna and sedimentary organic matter off Central Chile: response to changes caused by the 19971998 El Niño. Oceanol. Acta, 24: 313-328.

Neira, C., J. Sellanes, L.A. Levin \& W.E. Arntz. 2001b. Meiofaunal distributions on the Peru margin: relationship to oxygen and organic matter availability. Deep-Sea Res. I, 48: 2453-2472.

Neira, C., I. King, G. Mendoza, J. Sellanes, P. De Ley \& L.A. Levin. 2013. Nematode community structure along a central Chile margin transect influenced by the oxygen minimum zone. Deep-Sea Res. I, 18: 1-15.

Parsons, T.R., Y. Maita \& C.M. Lalli. 1984. A manual of chemical and biological methods for seawater analysis. Pergamon Press, Oxford, 173 pp.

Palma, M., E. Quiroga, V.A. Gallardo, W.A. Arntz, D. Gerdes, W. Schneider \& D. Hebbeln. 2005. Macrobenthic animal assemblages of the continental margin off Chile $\left(22^{\circ}\right.$ to $\left.42^{\circ} \mathrm{S}\right)$. J. Mar. Biol. Assoc. U.K., 85: 233-245.

Pfannkuche, O. \& T. Soltwedel. 1998. Small benthic size classes along the European continental margin: spatial and temporal variability in activity and biomass. Prog. Oceanogr., 42: 189-207.
Quiroga, E., J. Sellanes, W.E. Arntz, D. Gerdes, V.A. Gallardo \& D. Hebbeln. 2009. Benthic megafaunal and demersal fish assemblages on the Chilean continental margin: The influence of the oxygen minimum zone on bathymetric distribution. Deep-Sea Res. II, 56(16): 1112-1123.

Rodríguez, J.G., J. López \& E. Jaramillo. 2001. Community structure of the intertidal meiofauna along a gradient of morphodynamic sandy beach types in southern Chile. Rev. Chil. Hist. Nat., 74: 885-897.

Rutllant, J., B. Rosenbluth \& S. Hormazabal. 2004. Intraseasonal variability in the local wind forcing of coastal upwelling off Central Chile $\left(30^{\circ} \mathrm{S}\right)$. Cont. Shelf Res., 24: 789-804.

Scheffer, F. \& P. Schachtschabel. 1984. Lehrbuch der Bodenkunde. Enke Verlag, Stuttgart, 442 pp.

Sellanes, J. \& C. Neira. 2006. ENSO as a natural experiment to understand environmental control of meiofaunal community structure. Mar. Ecol., 27: 3143.

Sellanes, J., C. Neira \& E. Quiroga. 2003. Composición, estructura y flujo energético del meiobentos frente a Chile central. Rev. Chil. Hist. Nat., 76: 401-415.

Sellanes, J., C. Neira, E. Quiroga \& N. Teixido. 2010. Diversity patterns along and across the Chilean margin: a continental slope encompassing oxygen gradients and methane seep benthic habitats. Mar. Ecol., 31: 111-124.

Sellanes, J., E. Quiroga, C. Neira \& D. Gutiérrez. 2007. Changes of macrobenthos composition under different ENSO cycle conditions on the continental shelf off central Chile. Cont. Shelf Res., 27: 1002-1016.

Sievers, H. \& A. Vega. 2000. Respuesta físico-química de la bahía de Valparaíso a la surgencia generada en punta Curaumilla y al fenómeno El Niño. Rev. Biol. Mar. Oceanogr., 35(2): 153-168.

Silva, N. \& A. Valdenegro. 2003. Evolución de un evento de surgencia frente a Punta Curaumilla, Valparaíso. Invest. Mar., Valparaiso, 31(2): 73-89.

Silva, N., C. Vargas \& R. Prego. 2011. Land-ocean distribution of allochthonous organic matter in the surface sediments of the Chiloé and Aysén interior seas (Chilean Northern Patagonia). Cont. Shelf Res., 31: 330-339.

Smallwood, B.J. \& G.A. Wolff. 2000. Characterization of organic matter in sediments underlying the oxygen minimum zone at the Oman Margin, Arabian Sea. Deep-Sea Res. II, 47: 353-375.

Stead, R., A. Schmidt, S. Pereda, M. Anzieta, G. Asencio \& E. Clasing. 2011. Relación de la comunidad de meiofauna y bioquímica del sedimento en canales norpatagónicos. Cienc. Tecnol. Mar, 34(1-2): 49-68. 
Teixeira, H., S.B. Weisberg, A. Borja, J.A. Ranasinghe, D.B. Cadien, R.G. Velarde, L.L Lovell, D. Pasko, C.A. Phillips, D.E. Montagne, K.J. Ritter, F. Salas \& J.C. Marques. 2012. Calibration and validation of the AZTI's Marine Biotic Index (AMBI) for Southern California marine bays. Ecol. Indic., 12: 84-95.

Thiel, H., D. Thistle \& G.D. Wilson. 1975. Ultrasonic treatment of sediment samples for more efficient sorting of meiofauna. Limnol. Oceanogr., 20: 472-473.

Ulloa, O. \& S. Pantoja. 2009. The oxygen minimum zone of the eastern South Pacific. Deep-Sea Res. II, 56: 987991.

Received: 9 Januarv 2015; Accepted: 7 September 2015
Valderrama-Aravena, N., K. Pérez-Araneda1, J. AvariaLlautureo, C.E. Hernández, M. Lee \& A. Brante. 2014. Diversidad de nemátodos marinos de Chile continental y antártico: una evaluación morfológica y molecular. Rev. Biol. Mar. Oceanogr., 49(1): 147-155.

Veit-Köhler, G., D. Gerdes, E. Quiroga, D. Hebbeln \& J. Sellanes. 2009. Metazoan meiofauna within the oxygen-minimum zone off Chile: results of the 2001PUCK expedition. Deep-Sea Res. II, 56: 1093-1099.

Wieser, W. 1960. Benthic studies in Buzzards Bay. II. The meiofauna. Limnol. Oceanogr., 5: 121-137.

Zeppilli, D., L. Bongiorni, A. Cattaneo, R. Danovaro \& R.S. Santos. 2013. Meiofauna assemblages of the Condor Seamount (North-East Atlantic Ocean) and adjacent deep-sea sediments. Deep-Sea Res. II, 98: 87100 .

Annex 1. Meiofaunal community composition and its relative abundance (\%) in the study site.

\begin{tabular}{lccc}
\hline & Station 3 & Station 4 & Station 5 \\
\hline Nematoda & & & \\
Axonolaimidae sp.1 & 12 & 7 & 3 \\
$\quad$ Odontophora sp. & 14 & 13 & 6 \\
Cyatholaimidae sp.1 & & & 1 \\
Cyatholaimidae sp.2 & 3 & & \\
Enoplidae & 5 & & \\
Ironidae & 17 & 15 & 6 \\
Oncholaimidae & 8 & 4 & \\
Selachinematidae & 13 & & \\
Ceramonematidae & & & \\
Ceramonema sp. & & & 13 \\
Pselionema sp. & 6 & 13 & 13 \\
Desmoscolecidae sp.1 & 4 & & 8 \\
Desmoscolecidae sp.2 & 2 & 11 & \\
Desmoscolex sp. & 11 & 24 & 7 \\
Oxystominidae & & & \\
cf Halalaimus sp. & 5 & 13 & \\
Diplopeltidae sp.1 & & & 4 \\
Campylaimus sp. & & & 9 \\
Comesomatidae sp.1 & & & 3 \\
$\quad$ Sabatieria sp. & & & 2 \\
Chromadoridae sp.1 & & & 7 \\
Neochromadora sp. & & & 8 \\
Microlaimidae & & & 5 \\
Thoracostromopsidae & & & 5 \\
Acari (Halacarids) & & & \\
Acari sp.1 & 32 & 34 & 12 \\
Acari sp.2 & 23 & 14 & 7 \\
Acari sp.3 & 21 & 18 & 29 \\
Acari sp.4 & 16 & 5 & 7 \\
Acari sp.5 & & \\
Acari sp.6 & & 12 & 20 \\
Acari sp.7 & & 7 & 6 \\
\hline
\end{tabular}




\begin{tabular}{|c|c|c|c|}
\hline \multicolumn{4}{|l|}{ Continuation } \\
\hline & Station 3 & Station 4 & Station 5 \\
\hline Acari sp.8 & & & 14 \\
\hline Acari sp.9 & & 10 & 5 \\
\hline \multicolumn{4}{|c|}{ Copepoda (Harpacticoidea) } \\
\hline Copepoda sp.1 & 54 & 46 & 12 \\
\hline Copepoda sp.2 & 39 & 17 & 38 \\
\hline Copepoda sp. 3 & 7 & 25 & \\
\hline Copepoda sp.4 & & 12 & \\
\hline Copepoda sp.5 & & & 34 \\
\hline Copepoda sp.6 & & & 16 \\
\hline \multicolumn{4}{|l|}{ Nauplii larvae } \\
\hline Nauplii sp.1 & 47 & 40 & 29 \\
\hline Nauplii sp.2 & 36 & 29 & 23 \\
\hline Nauplii sp.3 & 17 & 12 & 8 \\
\hline Nauplii sp.4 & & 19 & 24 \\
\hline Nauplii sp.5 & & & 16 \\
\hline \multicolumn{4}{|l|}{ Cumacea } \\
\hline Dyastilidae sp.1 & & 100 & \\
\hline \multicolumn{4}{|l|}{ Polychaeta } \\
\hline Paraonidae sp.1 & & & 100 \\
\hline \multicolumn{4}{|l|}{ Gastrotricha } \\
\hline Gastrotricha sp.1 & 75 & 60 & \\
\hline Gastrotricha sp.2 & 25 & 20 & 100 \\
\hline Gastrotricha sp.3 & & 10 & \\
\hline \multicolumn{4}{|l|}{ Kinorhyncha } \\
\hline Kinorhyncha sp.1 & & 100 & 60 \\
\hline Kinorhyncha sp. 2 & & & 40 \\
\hline \multicolumn{4}{|l|}{ Oligochaeta } \\
\hline Oligochaeta sp.1 & & 100 & \\
\hline
\end{tabular}

